\title{
THE INNOVATIVE PSYCHOLOGICAL CLIMATE: ITS SCOPE, STRUCTURE AND PARAMETERS
}

\author{
Oksana Ye. Furman \\ Ternopil National Economic University, Ukraine \\ E-mail: prfurman@yandex.ua
}

\begin{abstract}
The research reported here was designed to investigate the notion of psychological climate. The study presents the types of climate in organizations, namely, psychological, socio-psychological, organizational, innovative and psychological and carries out their scientific analysis. In addition, it presents the author's understanding of the concepts of innovative and psychological climate and its integrated parameters (psychological impact, educational communication, multi-motivation, positive and harmonious I-concept) as multi-dimensional phenomenon of modern education. The approach used in the research is based on the parallels drawn between the abilities and efficacy of human activity in certain geographical and psychological climate conditions, thus climatic determinism approach was referred to.

Key words: system of education, socio-psychological and organizational types of climate, innovative and psychological climate, climate parameters.
\end{abstract}

\section{Introduction}

It seems unreasonable to mention, but, in fact, the term "climate" was originally introduced by the ancient Greek astronomer Hipparchus in the second century BC. For two millennia, "persisted the idea that climate depends on location (inclination) of the sun above the horizon" (Бабиченко, Барабаш, \& Логвинов, 1984). In Greek, klima means inclination, in this case the earth's surface to sunlight.

In the early nineteenth century, Alexander von Humboldt noted that climate affects not only the position of the sun and various properties of the earth's surface, but has a significant effect on the location and movements of oceans. Later, the term climate was improved and repeatedly clarified. Currently, the term is mostly used to describe the general or average weather conditions of a certain region, including temperature, rainfall and wind. According to A. Monin, "climate is interacting parts of a single system, the atmosphere-ocean-land system or climate system. The initial state of the climate system will, external conditions remaining unchanged, completely determine its evolution in time" (Monin, 1986).

Humankind is aware of a "number of nearly constant variables which determine climate and its change: 1) external or astronomical covering glow of the sun, axial tilt, speed of revolving of the Earth around the sun; 2) geophysical, related to the properties of the Earth as a planet, namely, the size and mass of the planet, the gravitational and magnetic field, internal heat sources, planet 
surface; 3) meteorological, with the mass and chemical composition of the atmosphere being the

most important ones" (Monin, 1986, p. 17).

At the same time, climatic factors, such as temperature, wind, radiation, humidity, atmospheric pressure, and cloudiness significantly affect the patterns of our behaviour. In particular, it is proved that "strikes are most likely in a very hot and humid weather without any winds blowing as in such conditions we might witness increase in irritation, tension, aggression and so on. In chilly climates mental and physical human activity is more active, while in dry and humid climate our physical activity and mental concentration are much more complicated, and thus, a person acts in a passive way" (Корсини, Ауэрбаха, 2003, p. 289). Consequently, specified relationships between human and climatic factors confirm the soundness of the idea of "climatic determinism" (ibid. 289). Proponents of the latter believe that climate affects not only a person's physiological and social status, but his choice of the activities. Hence, for instance, increased or reduced performance.

On the other hand, climate research was introduced by Lewin, Lippitt and White in the 1930s (Ashkanasy, Wilderom, \& Peterson, 2000), which is viewed as nearly homogeneous units comprised of believes and perceptions with the consideration of the peculiarities of this homogeneity occurrence (Reichers \& Schneider, 1990, Moran \& Volkwein, 1992).

Thus, climate issues are relevant not only in understanding the natural interaction in the system "human - the world", but in the psychological understanding of interpersonal and intergroup ones where we deal with socio-psychological or organizational climates.

\section{Analysis of the Latest Researches of the Issue}

It is known that positive or negative atmospheres of interactions in the group significantly affect the emotional relationship between people and the content of their work. "The favourable or healthy climate" (Карамушка, 2003, p. 142) in the team accompanies technological progress of society, because it solves the issue of social and psychological potential in humanity, creating a culture of respect in relationships. In addition, it is a factor in the formation and activity of the individual, a prerequisite for stimulation of a person's creative and spiritual fulfilment. Amid its important features are the pleasure of work, a positive attitude and understanding between people, their unity, performance, stability, interpersonal and intergroup discourse, self-regulation and selforganization, and creative atmosphere.

However, it is worth mentioning that yet L. Tolstoy admitted the phenomenon of "school spirit", A. Makarenko, analyzing collective, applied as required the following options a "style" or "tone" and B. Paryhin, along with the term "climate", sometimes used the term "spiritual atmosphere" or "spirit of collective". Scientists claim that these are not identical. "The atmosphere is unstable, constantly variable side of the collective consciousness, and the climate refers not to certain situational changes in the mood of people, but only its resistant features" (Парыгин, 1981, pp. 9, 10). In addition, climate is "a part of the socio-psychological space of an organization, its psychological field" (Левин, 2009), which unfolds labour rights of a person as "bridgehead life personality" (Парыгин, 1981).

Psychological literature operates by such climate concepts as psychological, socio-psychological, organizational and others. The first one is described as the concept that justifies the emotional mood, moral and psychological state of the person and is expressed through the communication process. Through its action, personal and business relationships of team members, their values and norms are displayed on the affective level. At the same time, the socio-psychological climate (SPC), firstly, highlights the system of relationships between team members (reactions, social actions), that is interpersonal or directly inter-relational. The latter is formed as "a qualitative structure influencing livelihoods within a small group. In the group of 7-20 people there is SPC, and in the group of 50-100 or more people interpersonal relationships are grouped into three to five separate substructures" (Казмиренко, 1993, pp. 106, 107). The relations which exist between them are examined by organizational climates (OC) that also depend on the processes in single socio-psychological climates. 
OF PSYCHOLOGY IN THE $21^{\text {st }}$ CENTURY Vol. 9, No. 1, 2015

\section{Research Purpose}

It appears plausible that the comfort and efficiency of the group work depends greatly on the individual characteristics of its members. There is a wide scope of variables that can influence the quality of the climate and its perception by the members. However, having considered all previously revealed aspects of climate, such as psychological, socio-psychological, organisational, innovative-psychological, it appears reasonable to provide a conceptual description of the latter from the perspective of its educational integration in the condition of current transformations in this sphere. So far, the aim of the study is much predisposed by this necessity.

Moreover, the theme for the study is caused by multiple reasons, all of which will be briefly viewed below. Innovative-psychological climate is a commonplace within social organisation that is viewed as an integrated human activity. What is more, this climate influences the efficacy of the human activity while having an impact on the level of human ability to be involved. Positive climate leads to the scientific and technical progress within any particular society as it influences human creativity and the quality of interpersonal relations. Finally, it results in the active personal realization on both social and personal levels.

\section{Methodology of Research}

Many famous scientists pay attention to the study of socio-psychological and organizational climates (Аникеева, 1989; Парыгин, 1981; Казмиренко, 1993; Карамушка, 2003). In most cases, the authors define the first one as a societal and psychological phenomenon, which is formed through interpersonal relations in small groups; the second is characterized as reflecting the structural and dynamic properties of organizational environment, where people, sharing the same objectives and combined in a large group, can implement their ideas and intentions.

Interactive approach to climate formation states that climate is maintained as an interaction between individual and his surrounding or environment which is regulated by the peculiarities of information exchange (Moran \& Volkwein, 1992). In other words, interpersonal cooperation realised in common conversations and shared activities influences the formation of common meanings that, in its turn, has an impact on the comfort of team coexistence.

According to N. Anikeieva's conception, relations in the psychological climate are formed through the interaction of such methods as persuasion, infection, imitation and infusion that cause apparition of group compatibility (maximum result at minimum psychological expenses) or incompatibility as a psychological phenomenon (pp. 5, 11).

"The structure of SPC displays covers relation to: a) each other, b) common interests, c) the world (system of valuable personality orientations), and d) yourself (self-consciousness, self-attitude and well-being)" (Парыгин, 1981, pp. 12, 13). B. Paryhin also notes that the SPC is important in estimation of the overall emotional mood inside the collective. This position is also shared by N. Kolominskyi and other researchers (Коломінський, 2000). B. Shakurov writes that "the psychological aspect of climate is revealed in emotional, volitional and intellectual conditions and group properties, although they can be fixed on the social side" (Шакуров, 1982, pp. 55-69). "As for the socio-psychological aspect, it is demonstrated through unity, agreement, satisfaction, friendship, and solidarity" (Коломінський, 2000).

A brief review of psychological and socio-psychological climates enables the support of B.D. Paryhin (1981), L.M. Karamushka (2003), and N.L. Kolominskyi's (2000) opinions which state they should not be separated. This is evidenced by the fact that they cover processes of moral, psychological and social conditions of people, as well as the relationship between them, and most importantly, their overall emotional mood.

Similarly V.P. Kazmirenko (1993) notes that the SPC should not be identified with OC, as the first one often depicts direct interpersonal relationships that are inherent in small groups, whereas the second shows intergroup ones, although it considers interpersonal relationships. This is a new methodological level and, according to this approach, both direct and indirect relationships should undergo analysis. Thus, OC has its nature and "is reflected in the system of three main parameters: socio-psychological space organization, information and business 
exchanges, ways and means to revitalize the elements of the organization at all levels" (Казмиренко, 1993, p. 108).

Thus, based on theoretical considerations of socio-psychological and organizational climates, learning of experience of the fundamental comprehensive experiment in module-developing learning (Фурман, 1997), the term "innovative psychological climate" (IPC) is introduced.

IPC provides an exceptional learning environment, where realization of social activity of participants of educational cooperation takes place and is reflected in the following of its basic parameters: a) socio-psychological impact functioning in the context of social and cultural space and time, b) educational communication as information, business, and self-sensual exchanges and c) multi-motivation as a way of activation of students' educational activity. In psychological and pedagogical unity they define the development of positively harmonious students' I-concept.

It should be stated that under the parameters followed by V. Kazmirenko, "those complex or single features that, on the one hand, are properties of the analyzed reality, on the other hand, can be used as variables of its measurement" are meant (Казмиренко, 1993, p. 81). In addition, they are used to call the set of "... leading variables which allow ... to evaluate peculiarities of the socio-psychological processes and the organizational climate" (Казмиренко, 1993, p. 129).

Parameters as characteristics do not arise spontaneously, without any reason. They are caused by the factors which are "a condition, driving force of any process, phenomenon; factor; ... " (Бусел, 2009 , p. 1526). In other words, the above-mentioned parameters arise under such integrated cyclically motivated factors: knowledgeable and situational, normative and motivational, value-active, self-realizing and post-active. The latter is projected and activated due to module-developing cycle periods as a separate group of psycho-pedagogical conditions and causes of educational common activity of teachers and students. At the same time, "set parameters values and features ..." (Бусел, 2009, p. 588) are called "criteria ..." (or even "a measure of truth ..." (Бусел, 2009, p. 588). Thus, four criteria groups of IPC that explain mentioned above parameters were differentiated: a) determination (feasibility, appropriateness), b) awareness (intentionality, meaningfulness), c) efficiency (pithiness, productivity), d) coordination (balance, proportionality).

\section{Results of Research}

IPC functions in a module-developing educational system (Фурман, 1997; Фурман, 2001), which, as a research project of innovative education, realizes a socio-cultural paradigm of social development in Ukraine; aims at scientific and practical grounding of the school of future which is represented by school of culture and spirituality; is viewed as the unity of a multidisciplinary theory, vita-cultural methodology, social and psychological technologies and practice to experiment in educational institutions; implements the requirements of ideas of culture and development, principles of mentality, spirituality, evolution and modularity patterns, patterns of functioning of didactic, educational, content and other modules; is based on the theory of educational activities which explain the mechanisms of human appearance as a subject himself, personality, individuality and the universe through immersion into social experience (Гуменюк, 1998; Гуменюк, 2003; Гуменюк, 2008; “Модульно-розвивальна система як соціокультурна організація”, 2001; Фурман, 1997; Фурман, 2001). A module-developing system is being gradually implemented in Ukrainian schools as longitudinal socio-psychological experiment and, therefore, follows the laws and methods of social engineering and prognostication.

It should be noted that IPC, which operates in this study, covers the content of socio-psychological (developmental cooperation arises positive emotions, moods, installations, motives, news norms and senses are formed, different interpersonal relationships such as parity and development are shaped and organizational climate (educational organization, where there are interpersonal and intergroup relations). In addition, influence, communication, multi-motivation and I-concept are reflected in the system of the above mentioned parameters. Under the innovation and psychological climate one understands a set of stable features that essentially define module-developing system, affect the forms of the activity of participants in the group, and their emotional and moral moods and intergroup relationships. Its structure includes: a) psychological impact and its classes (cognitive and subjective effects, regulatory and personal interplay, value-individual interplay, 
OF PSYCHOLOGY

IN THE $21^{\text {st }}$ CENTURY Vol. 9, No. 1, 2015

18

spiritual and universe self-creation); b) educational communication with its aspects (communicative aspect as information, interactive as business exchange, perceptive as sense creative, intuitive as self-sensitive); c) multi-motivation with its scope and terms of deployment (cognitive motivation, practical motivation, mental motivation, self-motivation); d) positively harmonic I-concept and its components (cognitive: I-image, emotional and evaluative: I-attitude, action-creative: I-act, spontaneously spiritual: I-spiritual).

According to B. Paryhin, one of the most common indicators of SPC is self-attitude, feelings which surround the individual identity (Парыгин, 1981, pp. 13, 15). So, the central identity formation becomes I-concept of the person, who theoretically and empirically is being investigated in this research as a fourth IPC parameter (Гуменюк, 2008).

The term "innovative psychological climate" in the research emerged, on the one hand, from the analysis of practical activity which is based on the experience of experimentation in Ukrainian schools. On the other hand, it has arisen from the theoretical combination of knowledge in different subjects (psychological theories and concepts, for example), which made it possible to distinguish its parameters. Thus, IPC is the phenomenon of multi-module developing training system, which naturally occurs in the final stages of the experiment, integrates achievements of innovative and educational, scientific and research activities of the comprehensive institution (school, lyceum) and is forecasted by the theory of educational activities as a fundamental condition of implementing innovative educational system.

\section{Summing-up}

Innovative and psychological climate, which keeps phenomena of influence, multi-motivation, communication, I-concept, represents itself as a self-sufficient integrity of persistent features of a school environment that are essentially inherent to module-developing education and cause various forms of mental activity of students, their emotional state and moral mood, effectiveness of interpersonal and intergroup relationships which develop rhythmically each subject, personality, selfhood and someone universe. Simultaneously, innovative and psychological climate is actually available, complex phenomenon of school life which is influenced by several factors: 1) the socio-psychological atmosphere, or "humanitarian aura" of society referring mainly to the sociocultural sphere of influence; 2) "school spirit" as the scope of educational parity interaction and communication in the space of a comprehensive institution; 3) trust-business nature of interpersonal relations which is mainly the scope of multi-motivation of educational activity of each participant of the training; 4) special actively-reflective state of mind of a teacher and student as their positive and harmonic I-concept.

In summary, the innovative and psychological climate, integrating both features of school organizational climate and socio-psychological climates of educational groups and the content of innovative-experimental activity of a certain school staff is an empirical phenomenon, which occurs in the course of module-developing system and is meaningful as a constituent part of a high parametric complexity.

A final implication for future research is how the efficacy of innovative and psychological climate can be studied within the context of school functioning. These conclusions emphasise the importance of educational surrounding scanning.

\section{References}

Anikeeva, N. P. (1989). Psihologicheskiy klimat v kollektive: kniga dlia uchitelia. [Psychological climate in the team: book for a teacher]. Moscow: Psosveshchenie.

Ashkanasy, N. M., Wilderom, C. P. M., \& Peterson, M. F. (2000). Introduction. In N. M. Ashkanasy, C. P. M. Wilderom \& M. F. Peterson (Eds.), Handbook of organizational culture and climate (pp. 1-18). London: Sage.

Busel, T. V. (Ed.). (2009). Velykiy tlumachnyi slovnyk suchasnoi ukrainskoi movy [Big dictionary of the modern Ukrainian language]. Kyiv, Irpin: VTF Perun. 
Furman, A. V. (1997). Modulno-rozvyvalne navchannia: pryntsypy, umovy, zabezpechennia [Modular-developmental education: Principles, conditions and implementation]. Kyiv: Pravda Yaroslavychiv.

Furman, A. V. (2001). Teoriia osvitnioi dialnosti iak metasystema [Theory of educational activity as metasystem]. Psychology and Society, 3, 105-144.

Gumeniuk (Furman), O. Ie. (1998). Modulno-rozvyvalne navchannia: socialno-psychologichniy aspekt. [Modular-developmental education: social and psychological aspects].

Gumeniuk (Furman), O. Ie. (2003). Psychologiia vplyvu [Psychology of influence]. Ternopil: Economichna dumka.

Gumeniuk (Furman), O. Ie. (2008). Teoriia i metodologiia innovatsiyno-psychologichnogo klimatu zagalnoosvitniogo zakladu [Theory and methodology of innovative psychological climate of educational establishment]. Yalta, Ternopil.

Kazmyrenko, V. P. (1993). Sotsialnaia psichologiia organizatsii [Social psychology of organisations]. Kyiv: MZUUP.

Karamushka, L. M. (2003). Psychologiia upravliniia [Psychology of management]. Kyiv: Milenium.

Kolominskiy, N. L. (2000). Psychologiia menedgmentu v osviti (sotsialno-psychologichnyi aspekt). [Psychology of management in education (socio-psychological aspect)]. Kyiv: MAUP.

Korsini, R., Auerbaha, A. (Ed.). (2003). Psichologicheskaia entsiklopediia [Psychological encyclopedia]. Sains PetersburgP: Piter.

Levin, K. (1982). Tipy konfliktov [Types of conflicts]. Psychology of personality. Gippenreiter, Iu. B., Puzyreia, A. A. Moscow: MGU.

Monin, A. S. (1986). An introduction to the theory of climate. Holland: D. Reidel Publishing Company.

Moran, E. T., \& Volkwein, J. F. (1992). The cultural approach to the formation of organisational climate. Human Relations, 45, 19-47.

Paryhin, B. D. (1981). Sotsialno-psychologichnyi klimat kollektyva: Puti i metody izucheniia [Socio-psychological climate of the team: The ways and methods of investigation]. Iadova, V.A. (Ed.). L.: Nauka.

Reichers, A., \& Schneider, B. (1990). Climate and culture: An evolution of constructs. In B. Schneider (Ed.), Organisational climate and culture (pp. 5-39). Oxford: Jossey-Bass.

Shakurov, R. H. (1982). Sotsialno-psychologicheskie problemy rukovodstva pedagogicheskim kollektivom [Socio-psychological problems of pedagogical body's management]. Moscow: Pedagogica.

Advised by Tetiana Shyriaeva, National University of Ostroh Academy, Ukraine 